\title{
PENGARUH ELECTRONIC WORD OF MOUTH DI MEDIA SOSIAL INSTAGRAM TERHADAP MINAT BELI KONSUMEN PADA DISTRO BATTLEBOOM PALU
}

\author{
CHANDRA ANANTA PUTRA \\ JOHNNY TANAMAL \\ RAHMAT MUBARAQ \\ Jurusan Manajemen, Fakultas Ekonomi, Universitas Tadulako \\ Email: Chandorra92@gmail.com
}

\begin{abstract}
This study aims to determine and analyze the influence of electronic word of mouth variables in social media Instagram of consumer buying interest in Battleboom Palu Distro. The type of research used is quantitative (indicating the relationship between variables). The population in this study is the whole followers account Instagram Distro Battleboom Palu number is not known with certainty The sampling technique to determine the sample that will be use in this research using non probability sampling technique, that is purposive sampling. With the number of samples as much as 100 respondents. Data collection using questionnaire. Data analysis method used multiple linear regression analysis. The results showed that (1) There is influence of electronic word of mouth simultaneously to consumer buying interest in Distro Battleboom Palu (2) partially electronic word of mouth sub variable content and intensity influential significant to consumer buying interest in Distro Battleboom Palu (3) and partially electronic word of mouth sub variable negative valence of opinion and positive valence of opinion have no significant effect on consumer buying interest in Distro Battleboom Palu.
\end{abstract}

Keywords : electronic word of mouth, consumer buying interest.

\begin{abstract}
ABSTRAK
Penelitian ini bertujuan untuk mengetahui dan menganalisa pengaruh dari variabel electronic word of mouth di sosial media instagram terhadap minat beli konsumen di Distro Battleboom Palu.Jenis penelitian yang digunakan adalah kuantitatif (menunjukan hubungan antar variabel). Populasi dalam penelitian ini adalah seluruh followers akun instagram Distro Battleboom Palu jumlahnya tidak diketahui dengan pasti. Teknik pengambilan sampel untuk menentukan sampel yang akan digunakan dalam penelitian ini menggunakan Teknik non probability sampling, yaitu purposive sampling. Dengan jumlah sampel sebanyak 100 responden. Pengambilan data menggunakan kuesioner. Metode analisis data yang digunakan adalah analisis regresi linear berganda. Hasil penelitian menunjukan bahwa (1) Terdapat pengaruh electronic word of mouth secara simultan terhadap minat beli konsumen di Distro Battleboom Palu (2) secara parsial electronic word of mouth sub variabel content dan intensity berpengaruh signifikan terhadap minat beli konsumen di Distro Battleboom Palu (3) dan secara parsial electronic word of mouth sub variabel negative valence of opinion dan positive valence of opinion berpengaruh tidak signifikan terhadap minat beli konsumen di Distro Battleboom Palu.
\end{abstract}

Kata Kunci : electronic word of mouth, minat beli konsumen

\section{PENDAHULUAN}

Sistem informasi saat ini sangat berkembang terutama internet, dengan perkembangan teknologi informasi tersebut, kegiatan pemasaran yang saat ini diminati oleh pemasar adalah social-media marketing. Bukan hanya sebatas mass communication tapi sudah memasuki komunikasi yang memiliki banyak peminat di era sekarang yaitu digital communication. Komponen penting pemasaran digital adalah media sosial. Media sosial merupakan sarana bagi konsumen untuk berbagi informasi teks, gambar, audio, dan video satu sama lain dengan perusahaan, dan sebaliknya. (Kotler \& Keller, 2016:643). Seiring dengan perubahan waktu, fungsi media sosial tidak hanya menjadi sarana komunikasi tetapi berubah menjadi sarana perdagangan. Saat ini sudah banyak perusahaan atau pengusaha yang menggunakan media sosial sebagai sarana untuk mempromosikan produk yang akan 


\section{Putra C.A}

mereka jual/pasarkan, melalui media sosial tersebut diharapkan akan membentuk komunikasi pemasaran yang efektif secara online yaitu electronic word of mouth (eWOM).

Trend belanja online melalui media sosial menjadi fenomena baru dalam paradigma berbelanja masyarakat Indonesia khususnya Kota Palu. Masyarakat lebih senang meluangkan waktu untuk berbelanja online dari pada berkunjung ke toko secara langsung untuk membeli barang yang mereka inginkan. Mengomunikasikan produk dan jasa melalui online shop kini banyak dilakukan oleh pemasar. Salah satu media online yang efektif adalah media sosial instagram. Instagram juga merupakan salah satu bentuk social media yang paling cepat pertumbuhannya. Instagram hadir dengan fungsi lebih dari sekedar marketing tools. Instagram dapat memicu electronic word of mouth di social media sehingga memengaruhi minat beli konsumen.

Electronic word of mouth (eWOM) merupakan pernyataan yang dibuat oleh konsumen aktual, potensial atau konsumen sebelumnya mengenai produk atau perusahaan dimana informasi ini tersedia bagi orang-orang ataupun institusi melalui media internet (Thurau et al, 2004). Goyette et al (2010:10) membagi electronic word of mouth (eWOM) dalam empat dimensi yaitu : content, negative valence of opinion, positive valence opinion, dan intensity. Content adalah isi informasi dari media sosial berkaitan dengan produk dan jasa, negative valence of opinion adalah pendapat konsumen negatif mengenai produk, jasa dan brand, positive valence of opinion adalah pendapat konsumen positif mengenai produk, jasa dan brand dan intensity (intensitas) dalam electronic word of mouth (eWOM) adalah banyaknya pendapat yang ditulis oleh konsumen dalam sebuah situs jejaring sosial.

Berdasarkan pada latar belakang yang telah dijelaskan sebelumnya maka permasalahan yang diteliti dalam penelitian ini antara lain: (1) Apakah variabel electronic word of mouth (eWOM) yang terdiri dari content, negative valence of opinion, positive valence of opinion dan intensity berpengaruh secara simultan terhadap minat beli konsumen pada distro Battleboom di Kota Palu, (2) Apakah content berpengaruh secara parsial terhadap minat konsumen membeli produk pada distro Battleboom di Kota Palu, (3) Apakah negative valence of opinion berpengaruh secara parsial terhadap minat konsumen membeli produk pada distro Battleboom di Kota Palu, (4) Apakah positive valence of opinion berpengaruh secara parsial terhadap minat konsumen membeli produk pada distro Battleboom di Kota Palu, (5) Apakah intensity berpengaruh secara parsial terhadap minat konsumen membeli produk pada distro Battleboom di Kota Palu.

Adapun tujuan penelitian ini antara lain: (1) Untuk mengetahui pengaruh variabel electronic word of mouth (eWOM) yang terdiri dari content, negative valance of opinion, positive valence of opinion, dan intensity secara simultan terhadap minat beli konsumen pada distro Battleboom di Kota Palu, (2) Untuk mengetahui pengaruh variabel content secara parsial terhadap minat konsumen membeli produk pada distro Battleboom di Kota Palu, (3) Untuk mengetahui pengaruh variabel negative valence of opinion secara parsial terhadap minat konsumen membeli produk pada distro Battleboom di Kota Palu, (4) Untuk mengetahui pengaruh variabel positive valence of opinion secara parsial terhadap minat konsumen membeli produk pada distro Battleboom di Kota Palu, (5) Untuk mengetahui pengaruh variabel intensity secara parsial terhadap minat konsumen membeli produk pada distro Battleboom di Kota Palu.

\section{KAJIAN LITERATUR DAN PENGEMBANGAN HIPOTESIS}

\section{Electronic Word of Mouth (eWOM)}

Thurau et al. (2004) mengatakan electronic word of mouth (eWOM) merupakan pernyataan yang dibuat oleh konsumen aktual, potential atau konsumen sebelumnya mengenai produk atau perusahaan dimana informasi ini tersedia bagi orang-orang ataupun institusi melalui media internet. Jansen (2009) menyebutkan bahwa meskipun mirip dengan bentuk word of mouth (WOM), electronic word of mouth (eWOM) menawarkan berbagai cara untuk bertukar informasi, banyak juga diantaranya secara anonim atau secara rahasia. Hal ini dilakukan untuk memberikan kebebasan geografis dan temporal, apalagi 
electronic word of mouth (eWOM) memiliki setidaknya beberapa diantaranya bersifat permanen berupa tulisan. Penting untuk mengetahui perbedaan antara word of mouth marketing (WOM tradisional) dengan electronic word of mouth (eWOM). Perbedaannya dapat dilihat dari dua hal yang signifikan, yaitu:

1. bersifat elektronik sesuai keadaan atau kondisi dan tanpa ada komunikasi tatap muka.

2. pengirim pesan menyampaikan pesan kepada penerima yang tidak mencari informasi, dan belum tentu bersedia untuk memberikan perhatian mereka pada informasi tersebut.

Perbedaan antara word of mouth (WOM) dan electronic word of mouth (eWOM) dapat dibedakan berdasarkan pada media yang digunakan. Penggunaan word of mouth (WOM) tradisional biasanya bersifat face to face (tatap muka). Penggunaa word of mouth (WOM) biasanya bersifat secara online melalui cyberspace. Seiring berkembangya kemajuan teknologi, tempat fisik dimana word of mouth terjadi telah berubah dari face to face ke cyberspace.

Word of Mouth online adalah proses word of mouth dengan menggunakan media internet. Melakukan aktivitas dalam electronic word of mouth (eWOM), konsumen akan mendapatkan tingkat transparansi pasar yang tinggi, dengan kata lain konsumen memiliki peran aktif yang lebih tinggi dalam siklus rantai nilai sehingga konsumen mampu mempengaruhi produk dan harga berdasarkan preferensi individu (Park dan Kim, 2008).

Internet telah memungkinkan timbulnya bentuk-bentuk baru dari platform komunikasi yang dapat memberdayakan providers dan konsumen dengan lebih baik, memungkinkan mereka untuk berbagi informasi dan pendapat baik dari business to consumer, dan dari consumer to consumer. Electronic word of mouth (eWOM) mengacu pada setiap pernyataan positif atau negatif yang dilakukan oleh para pelanggan potensial, pelanggan sebenarnya, atau mantan pelanggan tentang suatu produk atau perusahaan, yang tersedia bagi banyak orang dan lembaga melalui internet (Thurau et al, 2004). Goyette et al (2010:10) membagi electronic word of mouth (eWOM) dalam empat dimensi yaitu:

a. Content Adalah isi informasi dari media sosial berkaitan dengan produk dan jasa. Indikator dari content meliputi:

1) Informasi variasi model pakaian.

2) Informasi kualitas (kain, tekstur dan merk) pakaian.

3) Informasi mengenai harga yang ditawarkan.

b. Negative valence of opinion adalah pendapat konsumen negatif mengenai produk, jasa dan brand.

c. Positive valence of opinion adalah pendapat konsumen positif mengenai produk, jasa dan brand.

d. Intensity (intensitas) dalam electronic word of mouth (eWOM) adalah banyaknya pendapat yang ditulis oleh konsumen dalam sebuah situs jejaring sosial. Penelitian yang dilakukan oleh Goyette et al (2010) membagi indikator intensity sebagai berikut:

1) Frekuensi mengakses informasi dari media sosial.

2) Frekuensi interaksi dengan pengguna media sosial.

3) Banyaknya ulasan yang ditulis oleh pengguna media sosial.

\section{Social Media Instagram}

Instagram adalah sebuah aplikasi untuk membuat foto dan mengirimkannya dalam waktu cepat. Tujuan tersebut sangat dimungkinkan oleh teknologi internet yang menjadi basis aktivitas dari media social ini. Instagram lebih memaksimalkan fiturnya untuk komunikasi melalui gambar atau foto. Ketika bahasa visual mendominasi dunia internet, dari situlah para pelaku bisnis bisa memanfaatkan peluang yang terhampar di depan mata.

Instagram adalah sebuah aplikasi yang digunakan untuk membagi-bagikan foto dan video. Instagram sendiri masih merupakan bagian dari facebook yang memungkinkan teman facebook kita mem-follow akun Instagram kita. Makin populernya Instagram sebagai aplikasi yang digunakan untuk 


\section{Putra C.A}

membagi foto membuat banyak pengguna yang terjun ke bisnis online turut mempromosikan produkproduknya lewat instagram (Nisrina, 2015:137).

Instagram merupakan salah satu media jejaring sosial yang dapat dimanfaatkan penggunanya sebagai media pemasaran langsung. Melalui instagram-lah produk barang/jasa ditawarkan dengan meng-upload foto atau video singkat, sehingga para calon konsumen dapat melihat jenis-jenis barang/jasa yang ditawarkan.

\section{Minat Beli}

Schiffman dan Kanuk (2008) menjelaskan minat beli merupakan suatu dorongan yang dapat menyebabkan tingkah laku tertentu, tetapi minat tidak selalu konsisten dengan tingkah laku. Schiffman dan Kanuk juga menambahkan bahwa pengaruh eksternal, kesadaran akan kebutuhan, pengenalan produk dan evaluasi alternatif adalah hal yang dapat menimbulkan minat beli konsumen. Pengaruh eksternal ini terdiri dari faktor sosial, usaha pemasaran, dan faktor sosial budaya. Selain itu, Schiffman dan Kanuk (2008) juga menjelaskan bahwa indikator-indikator minat beli dijelaskan oleh beberapa komponen, yaitu:

1. Tertarik untuk mencari informasi tentang produk

Konsumen yang terangsang kebutuhannya akan terdorong untuk mencari informasi yang lebih banyak. Kotler dan Keller dalam Schiffman dan Kanuk (2008) membaginya dalam dua level rangsangan. Pertama, pencarian informasi yang lebih ringan (penguatan perhatian). Pada level ini, orang hanya sekedar lebih peka terhadap informasi produk. Kedua, level aktif mencari informasi, mencari bacaan, bertanya pada teman, atau mengunjungi toko untuk mempelajari produk tersebut.

2. Mempertimbangkan untuk pembeli

Melalui pengumpulan informasi, konsumen mempelajari merek-merek yang bersaing serta fitur merek tersebut. Melakukan evaluasi terhadap pilihan-pilihan dan mulai mempertimbangkan untuk membeli produk.

3. Tertarik untuk mencoba

Setelah konsumen berusaha memenuhi kebutuhan, mempelajari merek-merek yang bersaing serta fitur merek tersebut, konsumen akan mencari manfaat tertentu dari solusi produk dan melakukan evaluasi terhadap produk-produk tersebut. Evaluasi ini dianggap sebagai proses yang berorientasi kognitif. Maksudnya adalah konsumen dianggap menilai suatu produk secara sangat sadar dan rasional hingga mengakibatkan ketertarikan untuk mencoba.

4. Ingin mengetahui produk

Setelah memiliki ketertarikan unruk mencoba suatu produk, konsumen akan memiliki keinginan untuk mengetahui produk. Konsumen akan memandang produk sebagai sekumpulan atribut dengan kemampuan yang berbeda-beda dalam memberikan manfaat yang digunakan untuk memuaskan kebutuhan.

5. Ingin memiliki produk

Para konsumen akan memberikan perhatian besar pada atribut produk yang memberikan manfaat yang dicarinya. Akhirnya konsumen akan mengambil sikap terhadap produk evaluasi atribut dan membentuk niat untuk membeli atau memiliki produk yang disukai. 


\section{Kerangka Pemikiran}

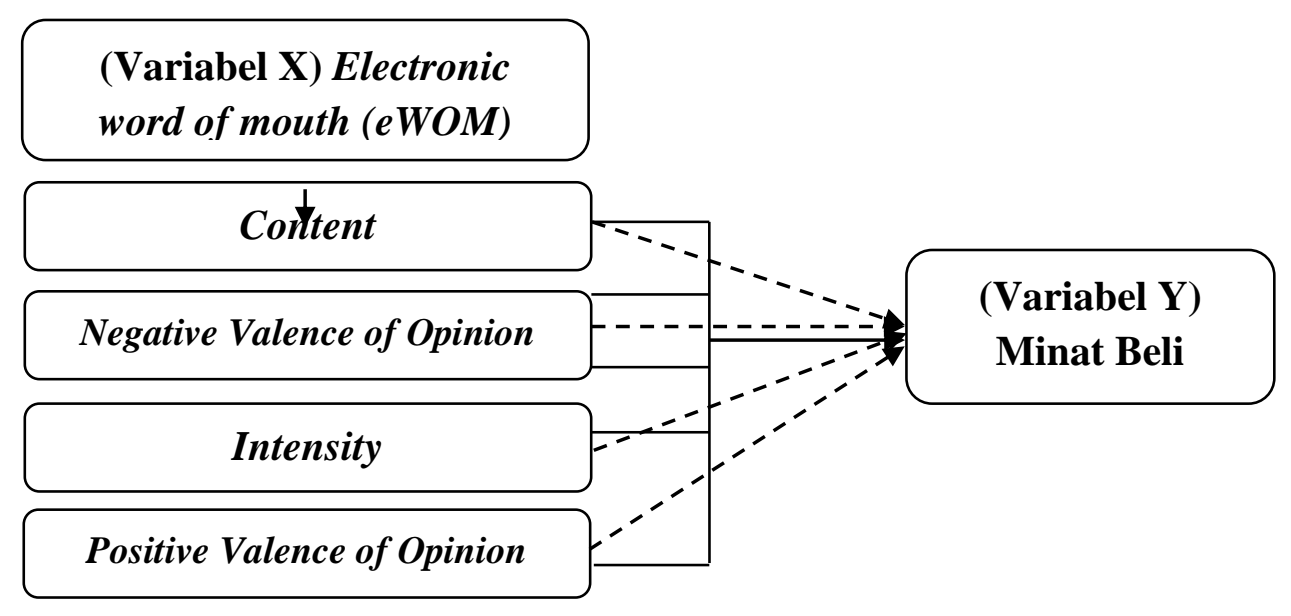

\section{Gambar 1. Kerangka Penelitian}

\section{HIPOTESIS}

Hipotesis adalah dugaan sementara atau jawaban atas permasalahan penelitian yang memerlukan data untuk menguji kebenaran dugaan tersebut. Dapat dikatakan bahwa hipotesis merupakan pernyataan hubungan yang mungkin terjadi antara dua variabel atau lebih. Maka hipotesis dari penelitian ini adalah:

1. Variabel electronic word of mouth (eWOM) yang terdiri dari content, negative valence of opinion, positive valence of opinion, intensity berpengaruh secara simultan terhadap minat beli konsumen pada distro Battleboom Palu.

2. Content berpengaruh secara parsial terhadap minat beli konsumen pada distro Battleboom Palu.

3. Negative valence of opinion berpengaruh secara parsial terhadap minat beli konsumen pada distro Battleboom Palu.

4. Positive valence of opinion berpengaruh secara parsial terhadap minat beli konsumen pada distro Battleboom Palu.

5. Intensity berpengaruh secara parsial terhadap minat beli konsumen pada distro Battleboom Palu.

\section{METODE PENELITIAN}

Berdasarkan klasifikasi tujuannya, penelitian ini termasuk ke dalam jenis kuantitatif karena penelitian ini bersifat menunjukan hubungan antar variabel (Sugiyono 2014:54). Peneliti melakukan survei untuk mengambil data di lapangan. Menurut Sugiyono (2014:80), penelitian survei adalah metode penelitian yang digunakan untuk mendapatkan data yang terjadi pada masa lampau, atau saat ini, tentang keyakinan, pendapat, karekteristik, perilaku, hubungan variabel untuk menguji beberapa hipotesis dari sampel yang diambil dari populasi tertentu, teknik pengumpulan data dengan pengamatan (wawancara atau kuesioner) yang tidak mendalam, dan hasil penelitian cenderung untuk digeneralisasikan.

Lokasi penelitian adalah tempat melakukan penelitian guna memperoleh data penelitian. Penelitian ini dilakukan di Kota Palu, dengan cara memberikan angket (kuesioner) kepada responden yang merupakan followers akun instagram Distro Battleboom Palu mengingat jumlah konsumen atau followers instagram distro Battleboom Palu yang tersebar dimana-mana. Adapun teknik pengumpulan data yang digunakan 


\section{Putra C.A}

1. Kuesioner merupakan teknik pengumpulan data yang dilakukan dengan cara memberi seperangkat pertanyaan atau pernyataan tertulis kepada responden untuk dijawabnya (Sugiyono, 2014:230). Kuesioner digunakan untuk mengetahui pendapat responden. Dalam hal ini responden hanya menjawab dengan cara memberi tanda tertentu pada alternatif jawaban yang disediakan. Kuesioner diberikan kepada responden melalui kuesioner online karena luasnya lingkup penelitian.

2. Studi kepustakaan dan penjelajahan internet, yaitu peneliti melakukan studi kepustakaan dengan cara menganalisis berbagai literatul yang ada seperti buku, dan jurnal, yang berkaitan dengan media sosial, electronic word of mouth, dan distro Battleboom. Selain itu, peneliti juga menggunakan dokumen-dokumen referensi pendukung seperti artikel, majalah, dsb. Peneliti juga melakukan penjelajahan internet untuk melakukan pencarian data dan informasi yang terkait dengan penelitian ini.

3. Wawancara, yaitu komunikasi atau pembicaraan dua arah dengan cara tanya jawab langsung yang dilakukan oleh peneliti dan Pemilik tempat penelitian untuk menggali informasi yang relevan dengan tujuan penelitian.

Teknik pengambilan sampel untuk menentukan sampel yang akan digunakan dalam penelitian ini menggunakan Teknik non probability sampling, yaitu purposive sampling. Purposive sampling adalah cara pengambilan sampel berdasarkan karakteristik tertentu. Unit sampel dalam penelitian ini adalah konsumen yang menjadi followers @battleboomstore. Populasinya merujuk pada jumlah followers akun Instagram @battleboomstore pada tanggal 23 juli 2017 yaitu 11.800 orang. Berdasarkan jumlah populasi tersebut untuk mengetahui besaran sampel dapat menggunakan rumus Yamane (Riduwan, 2007:210):

$$
\mathrm{n}=\frac{\mathrm{N}}{\mathrm{N}(\mathrm{d})^{2}+1}
$$

\section{Keterangan:}

$$
\begin{aligned}
& \mathrm{n}=\text { Jumlah sampel } \\
& \mathrm{N}=\text { Jumlah populasi } \\
& \mathrm{d}=\text { Nilai presisi }(10 \%) \\
& \mathrm{n}=\frac{\mathrm{N}}{\mathrm{N}(\mathrm{d})^{2}+1} \\
& \mathrm{n}=\frac{11.800}{11.800(0,1)^{2}+1} \\
& \mathrm{n}=\frac{11.800}{118+1} \\
& \mathrm{n}=\frac{11.800}{119} \\
& =99,159=99 \text { atau } 99 \text { orang }
\end{aligned}
$$

Stemper Jr. dalam Risnawati (2010:56) untuk mengukur dan menganalisis besarnya hubungan eWOM terhadap minat konsumen berbelanja di Distro Battleboom Kota Palu, menggunakan alat analisis statistic parametric regresi linear berganda (Multiple Regression Analisis). Menurut Sugiyono 
(2014:277), analisis regresi linear berganda digunakan oleh peneliti bila peneliti bermaksud meramalkan bagaimana keadaan (naik turunnya) variabel dependen (kriterium), bila dua atau lebih variabel independen sebagai faktor prediktor dimanipulasi (di naik turunkan nilainya). Persamaan regresi linear berganda dalam penelitian ini adalah:

$$
\mathbf{Y}=\mathbf{a}+\mathbf{b}_{1} \mathbf{X}_{1}+\mathbf{b}_{2} \mathbf{X}_{2}+\mathbf{b}_{3} \mathbf{X}_{3}+\mathbf{b} 4 \mathbf{X} 4
$$

Dimana:

$$
\begin{aligned}
& \mathrm{Y}=\text { Minat beli konsumen pada Distro Battleboom Palu } \\
& \mathrm{X}_{1} \quad=\text { Content } \\
& \mathrm{X}_{2} \quad=\text { Negative valence of opition } \\
& \mathrm{X}_{3} \quad=\text { Positive valence of opition } \\
& \mathrm{X} 4 \quad=\text { Intensity } \\
& \mathrm{a} \quad=\text { Konstanta } \\
& \mathbf{b}_{\mathbf{1}}-\mathbf{b}_{\mathbf{4}}=\text { Koefisien Regresi }
\end{aligned}
$$

\section{HASIL PENELITIAN}

Tabel 1

Hasil Analisis Regresi Linear Berganda

\begin{tabular}{|c|c|c|c|c|c|}
\hline \multicolumn{7}{|c|}{ Variabel Dependen Y = Loyalitas Pelanggan } \\
\hline \multirow{2}{*}{ Variabel Independen } & $\begin{array}{c}\text { Unstandardized } \\
\text { Coefficients }\end{array}$ & $\begin{array}{c}\text { Standardized } \\
\text { Coefficients }\end{array}$ & T & Sig \\
\cline { 2 - 6 } & $\mathbf{B}$ & $\begin{array}{c}\text { Std. } \\
\text { Error }\end{array}$ & Beta & & \\
\hline $\mathrm{C}=$ Costanta & 0,716 & 0,391 & & 1,829 & .070 \\
\hline Content $\left(\mathrm{X}_{1}\right)$ & 0,418 & 0,104 & 0,399 & 4,001 & 0,000 \\
\hline Negative Valence Of Opinion $\left(\mathrm{X}_{2}\right)$ & 0,011 & 0,038 & 0,022 & 0,300 & 0,765 \\
\hline Positive Valence Of Opinion $(\mathrm{X} 3)$ & 0,139 & 0,072 & 0,162 & 1,932 & 0,056 \\
\hline Intesity $(\mathrm{X} 4)$ & 0,256 & 0,094 & 0,269 & 2,714 & 0,008 \\
\hline
\end{tabular}

Sumber: Data yang diolah

Berdasarkan Tabel 1 di atas, maka dapat ditulis dalam bentuk persamaan regresi linear berganda sebagai berikut:

$$
Y=0,716+0,418 X_{1}+0,011 X_{2}+0.139 X_{3}+0.256 X_{4}
$$

Persamaan di atas menunjukan bahwa variabel independen yang dianalisis yaitu variabel (X1, X2, $\mathrm{X}$ 3, dan $\mathrm{X} 4$,) memberi pengaruh positif terhadap variabel dependen (Y), yaitu minat beli konsumen membeli di Distro Battleboom Palu. Untuk lebih jelasnya, penjelasan bentuk persamaan tersebut adalah sebagai berikut:

1. Nilai Konstanta sebesar 0,716, artinya jika variabel independen (content, negative valence of opinion, positive valence of opinion, dan intensity) bernilai 0 , maka variabel dependen (minat beli konsumen Distro Battleboom Palu) nilainya sebesar 0,716.

2. Dilihat dari nilai Beta, variabel independen $(X)$ yang berpengaruh paling dominan terhadap variabel dependen $(\mathrm{Y})$ adalah variabel content $\left(\mathrm{X}_{1}\right)$ karena variabel tersebut memiliki nilai Beta terbesar yaitu 0.399, sehingga dapat disimpulkan tidakan (content) pada Distro Battleboom Palu adalah faktor yang paling besar pengaruhnya terhadap minat beli konsumen. 


\section{Putra C.A}

3. Koefisien regresi variabel content $\left(\mathrm{X}_{1}\right)$ sebesar 0,399 , artinya apabila Distro Battleboom Palu mempunyai content yang baik, maka minat beli konsumen Distro Battleboom Palu meningkat sebesar 0,399 atau $39,9 \%$.

4. Koefisien regresi variabel negative valence of opinion $\left(\mathrm{X}_{2}\right)$ sebesar 0,022 , artinya jika negative valence of opinion naik satu satuan, maka minat beli konsumen Distro Battleboom Palu meningkat sebesar 0,022 atau $2,2 \%$.

5. Koefisien regresi variabel positive valence of opinion $\left(\mathrm{X}_{3}\right)$ sebesar 0,162 , artinya apabila positive valence of opinion di Distro Battleboom Palu naik satu satuan, maka minat beli konsumen Distro Battleboom Palu meningkat sebesar 0,162 atau 16,2\%.

6. Koefisien regresi variabel intensity $\left(\mathrm{X}_{4}\right)$ sebesar 0,269 , artinya apabila intensity di Distro Battleboom Palu naik satu satuan, maka minat beli konsumen Distro Battleboom Palu meningkat sebesar 0,269 atau $26,9 \%$.

\section{UJI F}

Tabel 2 Hasil Uji Simultan (Uji F)

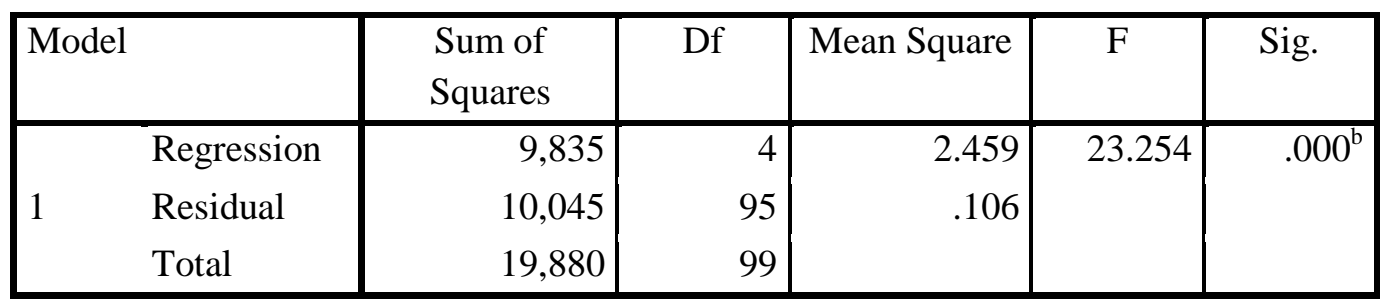

Sumber: Output SPSS 21

Berdasarkan Tabel 2 diperoleh nilai sig F yaitu 0.000, artinya nilai tersebut lebih kecil jika dibandingkan dengan nilai yang diisyaratkan yaitu $\alpha(0.05)$. Kesimpulannya dapat dinyatakan bahwa secara simultan komponen-komponen variabel electronic word of mouth yang terdiri dari content, negative valence of opinion, positive valence of opinion, dan intensity berpengaruh signifikan terhadap minat beli konsumen Distro Battleboom Palu. Nilai koefisien determinasi untuk variabel independen lebih dari 2 (dua) digunakan adjusted $R$ square.

\section{UJI T}

1. Berdasarkan hasil pengujian seperti yang terlihat pada tabel hasil analisis regresi linear berganda (Tabel 1) di atas, nilai probabilitas $t_{\text {sig }} X 1$ (content) lebih kecil dari nilai $\alpha(0,000<0,05)$. Artinya hipotesis kedua $(\mathrm{H} 2)$ dalam penelitian ini yaitu sense secara parsial berpengaruh signifikan terhadap minat beli konsumen Distro Battleboom Palu diterima.

2. Berdasarkan hasil pengujian seperti yang terlihat pada tabel hasil analisis regresi linear berganda (Tabel 1) di atas, nilai probabilitas $t_{\text {sig }} \mathrm{X} 2$ (negative valence of opinion) lebih besar dari nilai $\alpha$ $(0,765<0,05)$. Artinya hipotesis ketiga (H3) dalam penelitian ini yaitu negative valence of opinion secara parsial berpengaruh tidak signifikan terhadap minat beli konsumen Distro Battleboom Palu ditolak.

3. Berdasarkan hasil pengujian seperti yang terlihat pada tabel hasil analisis regresi linear berganda (Tabel 1) di atas, nilai probabilitas $\mathrm{t}_{\mathrm{sig}} \mathrm{X} 3$ (positive valence of opinion) lebih besar dari nilai $\alpha$ $(0,056<0,05)$. Artinya hipotesis keempat $(\mathrm{H} 4)$ dalam penelitian ini yaitu positive valence of opinion secara parsial berpengaruh tidak signifikan terhadap minat beli konsumen di Distro Battleboom Palu ditolak.

4. Berdasarkan hasil pengujian seperti yang terlihat pada tabel hasil analisis regresi linear berganda (Tabel 1) di atas, nilai probabilitas $\mathrm{t}_{\mathrm{sig}} \mathrm{X} 4$ (intensity) lebih kecil dari nilai $\alpha(0,008<0,05)$. Artinya 
hipotesis kelima (H5) dalam penelitian ini yaitu act secara parsial berpengaruh signifikan terhadap minat beli konsumen Distro Battleboom Palu diterima.

\section{Koefisien Determinasi}

Tabel 3 Uji Determinasi

\begin{tabular}{|l|r|r|r|r|r|}
\hline Model & $\mathrm{R}$ & $\mathrm{R}$ Square & $\begin{array}{c}\text { Adjusted R } \\
\text { Square }\end{array}$ & $\begin{array}{c}\text { Std. Error of } \\
\text { the Estimate }\end{array}$ & $\begin{array}{c}\text { Durbin- } \\
\text { Watson }\end{array}$ \\
\hline 1 & $.703^{\mathrm{a}}$ &, 495 &, 473 &, 32517 & 1,978 \\
\hline
\end{tabular}

Pada tabel 3 dapat dilihat nilai adjusted $R$ square sebesar 0,495. Nilai tersebut memberikan makna bahwa seluruh variabel independen yakni electronic word of mouth yang terdiri dari content, negative valence of opinion, positive valence of opinion, dan intensity secara serempak berpengaruh signifikan terhadap variabel dependen yaitu minat beli konsumen Distro Battleboom Palu dengan nilai sebesar 0,495 atau $49,5 \%$. Sedangkan selebihnya $(100 \%-49,5 \%=50,5 \%)$ dipengaruhi oleh variabel lain diluar model dalam penelitian ini.

\section{PEMBAHASAN PENELITIAN}

\section{Electronic Word Of Mouth (X) Terhadap Minat Beli Konsumen (Y) Distro Battleboom Palu}

Berdasarkan hasil penelitian ini yang dilakukan di Distro Battleboom Palu, secara umum strategi electronic word of mouth yang diterapkan Distro Battleboom Palu telah menciptakan berbagai jenis informasi bagi konsumen, yang meliputi: 1) Content yakni isi informasi dari media sosial berkaitan dengan produk dan jasa, 2) negative valence of opinion yakni pendapat konsumen negatif mengenai produk, jasa dan brand, 3) positive valence of opinion yakni pendapat konsumen positif mengenai produk, jasa dan brand, 4) intensity yakni banyaknya pendapat yang ditulis oleh konsumen dalam sebuah situs jejaring sosial.

Saat keempat jenis informasi tersebut dapat disampaikan dengan baik kepada konsumen mereka akan merasa terbantu, karena dengan adanya electronic word of mouth konsumen mudah untuk melihat dan membaca berbagai informasi yang disampaikan melalui akun instagram Distro Battleboom Palu, sehingga orang yang mencari informasi tersebut dan hasilnya bagus atau positif akan membuat keinginan membeli produk atau memunculkan minat pembelian produk tersebut.

Berdasarkan hasil uji $\mathrm{F}$ yang dilakukan, content, negative valence of opinion, positive valence of opinion, dan intensity secara simultan berpengaruh signifikan terhadap minat beli konsumen. Hasil ini memberikan arti bahwa hipotesis pertama yang menyatakan content, negative valence of opinion, positive valence of opinion, dan intensity secara simultan berpengaruh signifikan terhadap minat beli konsumen di Distro Battleboom Palu dapat diterima. Hal ini sejalan dengan penelitian terdahulu yang dilakukan oleh Laksmi dan Oktafani (2016), yang menyatakan bahwa electronic word of mouth bepengaruh secara signifikan terhadap minat beli konsumen.

\section{Pengaruh Content (X1) Terhadap Minat Beli Konsumen (Y) Distro Battleboom Palu}

Berdasarkan hasil uji parsial, penelitian ini menunjukkan bahwa content secara parsial berpengaruh signifikan terhadap minat beli konsumen Distro Battleboom Palu, berdasarkan hasil uji regresi linear berganda menunjukkan bahwa content berpengaruh positif terhadap minat beli konsumen. Hal ini berarti Distro Battleboom Palu memiliki informasi content yang baik sehingga konsumen merasa terbantu dan mudah mendapatkan informasi mengenai distro ini dan tentunya hal tersebut akan berdampak pada minat beli konsumen. 


\section{Putra C.A}

\section{Pengaruh Negative Valence Of Opinion (X2) Terhadap Minat Beli Konsumen (Y) Distro Battleboom Palu}

Negative valence of opinion dalam penelitian ini adalah bagaimana review atau informasi negative dan kekecewaan pelanggan yang pernah berbelanja di Distro Battleboom Palu. Ulasan negative dapat mengungkapkan masalah yang tidak berhasil, seperti kekurangan produk yang ditawarkan dan dapat mempengaruhi minat beli konsumen.

Berdasarkan hasil uji parsial, penelitian ini menunjukkan bahwa negative valence of opinion secara parsial berpengaruh tidak signifikan terhadap minat beli konsumen Distro Battleboom Palu. Berdasarkan hasil uji regresi linear berganda menunjukkan bahwa negative valence of opinion berpengaruh tidak positif terhadap minat beli konsumen. Artinya, Distro Battleboom Palu tidak memiliki negative valence of opinion dari konsumen, sehingga konsumen tidak melihat kekurangan dari Distro Battleboom Palu.

\section{Pengaruh Positive Valence Of Opinion (X3) Terhadap Minat Beli Konsumen (Y) Distro Battleboom Palu}

Positive valence of opinion dalam penelitian ini adalah bagaimana informasi mengenai keunggulan produk, dan kebanggaan orang lain yang pernah belanja di Distro Battleboom Palu. Ulasan positif konsumen terhadap sebuah produk bisa menjadi daya untuk memunculkan minat beli konsumen pada Distro Battleboom Palu.

Berdasarkan hasil uji parsial, penelitian ini menunjukkan bahwa positive valence of opinion secara parsial berpengaruh tidak signifikan terhadap minat beli konsumen Distro Battleboom Palu. Berdasarkan hasil uji regresi linear berganda menunjukkan bahwa positive valence of opinion berpengaruh tidak positif terhadap minat beli konsumen. Artinya, konsumen Distro Battleboom Palu belum pernah melihat ulasan positive valence of opinion dari konsumen yang lainnya.

\section{Pengaruh Intensity (X4) Terhadap Minat Beli Konsumen (Y) Distro Battleboom Palu.}

Berdasarkan hasil uji parsial, penelitian ini menunjukkan bahwa intensity secara parsial berpengaruh signifikan terhadap minat beli konsumen Distro Battleboom Palu. Berdasarkan hasil uji regresi linear berganda menunjukkan bahwa intensity berpengaruh positif terhadap minat beli konsumen. Hal ini berarti Distro Battleboom Palu memiliki ulasan intesity yang baik, sehingga konsumen tertarik untuk membeli di Distro Battleboom Palu.

\section{KESIMPULAN DAN SARAN}

\section{Kesimpulan}

Berdasarkan hasil pembahasan yang telah dikemukakan di atas, maka dapat disimpulkan sebagai berikut:

1. Variabel electronic word of mouth yang terdiri dari content, negative valence of opinion, positive valence of opinion, dan intensity berpengaruh signifikan secara simultan terhadap minat beli konsumen Distro Battleboom Palu

2. Content berpengaruh signifikan secara parsial terhadap minat beli konsumen Distro Battleboom Palu

3. Negative valence of opinion berpengaruh tidak signifikan secara parsial terhadap minat beli konsumen Distro Battleboom Palu

4. Positive valence of opinion berpengaruh tidak signifikan secara parsial terhadap minat beli konsumen Distro Battleboom Palu

5. Intensity berpengaruh signifikan secara parsial terhadap minat beli konsumen Distro Battleboom Palu 


\section{Saran}

1. Peneliti menyarankan Distro Battleboom Palu, tetap mempertahankan eWOM yang seperti sekarang ini. Terutama terus mempertahankan dan meningkatkan content postingan akun instagram mereka agar konsumen tertarik, yang tentunya akan menguntungkan bagi pihak Distro Battleboom Palu.

2. Peneliti juga menyarankan untuk meningkatkan intensity eWOM karena hal ini sangat perlu diperhatikan mengingat informasi yang tersebar antar individu tentang Distro Battleboom Palu, baik informasi positif maupun negatif keduanya dapat mempengaruhi minat beli konsumen. Informasi yang baik akan memberikan dampak yang baik,

3. Disarankan Distro Battleboom Palu untuk cepat dalam menanggapi jika tercipta negative valence of opinion, dengan melakukan sesuatu hal yang dapat membuat konsumen yang sebelumnya merasakan keraguan menjadi percaya kembali, sehingga bisa memunculkan minat beli

4. Bagi peneliti selanjutnya yang ingin meneliti atau melanjutkan penelitian ini, disarankan untuk meneruskan atau mengembangkan penelitian ini dengan mencari faktor lain yang dapat memengaruhi minat beli konsumen. Selain menyebarkan kuesioner, penelitian selanjutnya sebaiknya disertai dengan wawancara sehingga data yang diperoleh lebih lengkap dan dapat mengurangi data yang bersifat subyektif.

5. Kepada pihak-pihak yang berkepentingan diharapkan dapat memberikan saran-saran dan tanggapan untuk penulis dalam penelitian ini.

\section{REFERENSI}

Goyette, I., Richard, L., Bergeron, J. Dan Marticotte, F (2010). E-WOM Scale: Word-of-Mouth Measurement Scale for e-Services Context, Canadian Journal of Administration Sciences, 27(1),5-23.

Jansen, B. J. (2009). "Twitter Power : Tweet as Electronic Word Of Mouth". Journal of The American Society for Information Science and Technology.

Kotler, P. \& Keller, Kevin Lane. (2016). Marketing management. $15^{\text {th }}$ edition. England: pearson education, Inc.

Laksmi, Aditya Ayu \& Oktafani, Farah. (2016). dengan judul "Pengaruh electronic word of mouth terhadap Minat Beli Followers Instagram pada Warunk Upnormal". Jurnal Computech dan Bisnis, Volume 10 No. 2.

M. Nisrina. (2015). Bisnis Online Manfaat sosial Media Dalam Meraup Uang. Yogyakarta: Kobis.

Park, Do Hyung \& Kim Sara. (2008). The effects of consumer knowledge on messege processing. Elsevier, 12.

Riduwan \& Engkos Ahmad Kuncoro. (2007). Cara menggunakan dan memaknai Analisis Jalur (path analysis). Bandung: Alfabeta.

Risnawati. (2010). Pengaruh Pembelajaran Organisasi Terhadap Orientasi Kewirausahaan dan Orientasi Pasar Serta Dampaknya Terhadap Kinerja Koperasi. Tesis Pasca Sarjana Fakultas Ekonomi: Universitas Brawijaya.

Schiffman, L., \& Kanuk, J. (2008). Consumer behavior $\left(8^{\text {th }}\right.$ ed). New Jersey: Pearson Education Internasional.

Sugiyono. (2014). Metode penelitian manajemen: Pendekatan Kuantitatif, Kualitatif, Kombinasi, Penelitian Tindakan dan Penelitian Evaluasi, Cetakan Ke-3,Bandung: Alfabeta.

Thurau-Hennig., Gwinner, K.P., Walsh, G., \& Gremier, D,D. (2004). “Electronic 


\section{Putra C.A}

Word-Of-Mouth via Consumer-Opinion Platforms: What Motives Consumers to Articulate Themselves On The Intenet?". Journal Of Interactive Marketing. Vol.18, No.1. 